Terakreditasi Sinta 3 | Volume 3 | Nomor 4 (Special Issue) | Tahun 2020 | Halaman 393-402

P-ISSN 2615-725X | E-ISSN 2615-8655

http://diglosiaunmul.com/index.php/diglosia/article/view/100

\title{
ANALISIS KEBIJAKAN PEMBELAJARAN JARAK JAUH PADA PELAJARAN BAHASA INDONESIA DI MASA WABAH VIRUS CORONA
}

\author{
Policy Analysis of Distance Learning in Indonesian Lesson \\ during Corona Virus Epidemic
}

\author{
Triyanto \\ Pendidikan Bahasa dan Sastra Indonesia \\ Program Pascasarjana, Universitas Negeri Yogyakarta \\ Pos-el korespondensi: yantotri49@gmail.com
}

\begin{abstract}
This research aims to explore and describe a policy made by the government, specifically the policy related to distance learning during the Corona virus epidemic. The research method used is qualitative with a case study approach. Data collected were interviews with school principals, Indonesian language teachers, and observations in five classes, as well as distributing questionnaires with school principals, homeroom teachers, Indonesian language teachers, student guardians, and the students. Interview data were analyzed using "within case and cross-case analysis" between informants. The data obtained is processed into a database and made in the form of files to facilitate data processing. The results showed that SMP Muhammadiyah 1 Prambanan has implemented most of the distance learning policies instructed by the government through SE No. 4 of 2020. The learning responsibilities given to students are not burdensome in terms of materials, facilities, and infrastructures. The learning taught includes life skills during corona virus epidemic. The learning methods and the learning process are implemented in accordance with students' conditions. The feedback given by the teacher is still in the form of points and not in accordance with government instructions. The Indonesian language learning is carried out in accordance with government instructions.
\end{abstract}

Keywords: learning, distance, policy

\begin{abstract}
Abstrak: Penelitian ini bertujuan untuk mengeksplorasi dan mendeskripsikan satu kebijakan yang dibuat oleh pemerintah khususnya tentang kebijakan terkait pembelajaran jarak jauh di masa wabah virus Corona. Metode penelitian yang digunakan adalah kualitatif dengan pendekatan studi kasus. Data dikumpulkan melalui wawancara dengan kepala sekolah, guru bahasa Indonesia, dan observasi di lima kelas, serta penyebaran angket dengan kepala sekolah, wali kelas, guru bahasa Indonesia, wali murid, dan siswa. Data wawancara dianalisis menggunakan analisis saling-silang kasus antar informan. Data yang diperoleh diolah menjadi database dan dijadikan dalam bentuk berkas untuk mempermudah pengolahan data. Hasil penelitian menunjukkan bahwa SMP Muhammadiyah 1 Prambanan telah menerapkan sebagian besar kebijakan pembelajaran jarak jauh yang diinstruksikan pemerintah melalui SE Nomor 4 Tahun 2020. Beban pembelajaran yang diberikan kepada siswa tidak memberatkan dari segi materi, sarana, dan prasarana. Pembelajaran yang diajarkan telah mencakup kecakapan hidup dalam masa wabah virus Corona. Metode dan proses pembelajaran yang dilaksanakan sesuai dengan kondisi siswa. Umpan balik yang diberikan guru masih berupa poin dan belum sesuai dengan instruksi pemerintah. Pembelajaran Bahasa Indonesia yang dilakukan telah sesuai dengan instruksi pemerintah. Kata kunci: pembelajaran, jarak jauh, kebijakan
\end{abstract}

\section{A. PENDAHULUAN}

Negara-negara di seluruh dunia sedang mengalami pandemi yang sama.
Corona Virus Diseases 2019 atau biasa disebut Covid-19 merupakan spesies virus yang menyebabkan penderitanya 
mengalami gangguan pada pernafasan. WHO (World Health Organization) telah menetapkan pada tanggal 30 Januari 2020 sebagai kedaruratan kesehatan masyarakat yang meresahkan dunia. Indonesia sendiri telah melaporkan kasus pertama warga yang terkonfirmasi positif terjangkit virus Corona sebanyak 2 orang pada tanggal 2 Maret 2020 (Aziza, Aqmarina, \& Ihsan, 2020).

Virus Corona mengakibatkan berbagai sektor terdampak secara langsung, salah satunya adalah sektor pendidikan. Pemerintah telah mengeluarkan kebijakan melalui Surat Edaran (SE) Kementerian Pendidikan dan Kebudayaan (Kemendikbud) Nomor 4 Tahun 2020 tentang pelaksanaan kebijakan pendidikan dalam masa darurat penyebaran Corona Virus Disease (Covid-19). Sesuai edaran, sekolah-sekolah telah menerapkan pembelajaran jarak jauh dengan berbagai petimbangan dan persyaratan. Dalam SE telah dijelaskan bahwa belajar dari rumah untuk memberikan pengalaman belajar yang bermakna tanpa terbebani tuntutan menuntaskan capaian belajar sesuai dengan kurikulum untuk kenaikan kelas maupun kelulusan; belajar dari rumah dapat difokuskan pada pendidikan kecakapan mengenai wabah virus Corona; pembelajaran jarak jauh disesuaikan dengan kondisi siswa dengan mempertimbangkan kesenjangan akses atau fasilitas belajar di rumah; dan umpan balik hasil belajar tidak harus memberikan skor, pemberian nilai dapat berupa kualitatif.

Sebelum terjadinya wabah yang menyerang seluruh negara, terdapat metode pengajaran tanpa tatap muka yang sudah dikembangkan, yaitu Blended learning. Blended learning merupakan salah satu model pembelajaran yang menggabungkan pembelajaran tatap muka dan pembelajaran nontatap muka. pembelajaran mengandung campuran antara pola pembelajaran satu dengan yang lainnya (Hasamah, 2014, hal. 8).
Dunia saat ini tengah dipengaruhi oleh perkembangan teknologi yang berkembang secara cepat dan pesat. Hampir di seluruh aspek kehidupan manusia telah merasakan dampaknya, baik dampak positif maupun negatif, salah satunya dalam bidang pendidikan (Dewi, Murtinugraha, \& Arthur, 2018). Perkembangan teknologi yang dapat diakses dari seluruh kalangan masyarakat memberikan kemudahan dalam dunia pendidikan untuk memberikan pengalaman kepada siswa untuk belajar secara mandiri menggunakan bahan belajar tertulis maupun melalui komputer, gawai, dan internet, belajar seperti ini biasa disebut dengan istilah e-learning (Elvarita, Iriani, \& Handoyo, 2020; Tampubolon, Arthur, \& Daryati, 2017).

Alternatif pembelajaran yang dapat dilakukan pada kondisi pandemi adalah dengan cara jarak jauh seperti instruksi yang diberikan oleh Dinas Pendidikan. Pembelajaran jarak jauh merupakan suatu pendekatan yang dilaksanakan secara jarak jauh dan tidak saling tatap muka, baik antar guru dengan siswa maupun siswa dengan siswa yang lainnya. E-learning dapat menjadi pilihan dalam pelaksanaan pembelajaran jarak jauh karena berbasis internet yang tidak menuntut siswa dan guru untuk datang ke sekolah. Hal ini juga dapat memanfaatkan fasilitas perkembangan zaman (Yaumi, 2007). Sesuai dengan kondisi yang tidak memungkinkan untuk melangsungkan pembelajaran secara tatap muka, e-learning akan menjadi salah satu pilihan karena dapat menghemat waktu dan lebih fleksible (Ningtyas, Virnawati, Prasetiyo, Paramitta, \& Simri, 2008). Selain itu, e-learning dapat digunakan dengan akses yang lebih mudah, belajar secara mandiri, mandiri dalam belajar, dan menuntut siswa untuk lebih aktif dalam pembelajaran (Tigowati, Efendi, \& Budiyanto, 2017). Beberapa contoh situs atau aplikasi yang dapat digunakan untuk membantu dalam proses pembelajaran jarak jauh antara lain: e-mail, 
blog, Wikipedia, eportofolio, animasi, tautan video hingga jejaring sosial, seperti Facebook, Twitter, Youtube, Google Classroom, Edmodo, dan sebagainya (Noesgaard \& Ørngreen, 2015).

Seiring dengan berjalannya waktu, pembelajaran jarak jauh dapat dilihat proses dan hasilnya. Guru dan siswa menemukan hambatan-hambatan yang belum terpecahkan solusinya. Selain hal baru yang belum menjadi kebiasaan, pembelajaran jarak jauh memerlukan persiapan yang matang dan membutuhkan fasilitas yang memadai. Berdasarkan hasil wawancara saat observasi, terdapat beberapa guru yang mengeluhkan hambatan, terutama pada media yang digunakan mengingat guru senior kesulitan dalam hal teknologi. Hal serupa juga disampaikan oleh salah satu guru Bahasa Indonesia yang menyampaikaan, kesulitan dan hambatan yang ditemui, terlebih pada pelaajaran Bahasa Indonesia yang mengajarkan empat keterampilan berbahasa, yaitu: menyimak, berbicara, mendengarkan, dan menulis.

Hal ini yang membuat peneliti tertarik untuk melakukan penelitian mengenai kebijakan pendidikan pembelajaran jarak jauh selama wabah virus Corona di SMP Muhammadiyah 1 Prambanan, Sleman. Hal-hal yang akan spesifik dilakukan peneliti adalah untuk menjawab pertanyaan peneliti yaitu: Bagaimana pelaksanaan pengalaman pembelajaran di masa wabah virus Corona? Bagaimana pembelajaran tentang kecakapan hidup di masa pandemi? Bagaimana proses pembelajaran yang sesuai dengan kondisi siswa? Bagaimana proses penilaian dalam pembelajaran jarak jauh? Dan bagaimana proses belajar mengajar bahasa Indonesia di masa wabah virus Corona?

\section{B. METODE}

Metode penelitian yang digunakan adalah kualitatif dengan pendekatan studi kasus. Moleong (2014, hal. 6) mengemukakan bahwa penelitian kualitatif sebagai prosedur penelitian yang menghasilkan data deskriptif berupa katakata tertulis atau lisan dari orang-orang dan perilaku yang dapat diamati. Penelitian ini menggunakan observasi dan wawancara secara daring, serta menggunakan demografi angket peserta penelitian untuk mendapatkan data. Dalam penelitian ini pembelajaran yang dijadikan sampel adalah mata pelajaran bahasa Indonesia, dan sampel sekolah yang diambil meliputi berbagai pihak yang terlibat dalam proses Kebijakan Pembelajaran Jarak Jauh di SMP Muhammadiyah 1 Prambanan, Sleman, D.I. Yogyakarta. Data informan dalam penelitian ini disajikan dalam Tabel 1.

Dalam tahap analisis, semua data yang terkumpul dimasukkan ke dalam database komputer dalam bentuk berkas agar mudah untuk diakses. Data angket demografi informan dideskripsikan dan disajikan secara individual. Tema-tema hasil analisis yang diikuti pertanyaanpertanyaan dari para informan digunakan untuk menarasikan hasil penelitian.

\section{PEMBAHASAN}

Hasil penelitian ini dibagi dalam beberapa tema untuk mempermudah pendeskripsian hasil penelitian yakni; Memberikan pengalaman belajar; Kecakapa hidup mengenai pandemi; Pembelajaran sesuai dengan kondisi siswa; pemberian nilai; dan pembelajaran Bahasa Indonesia. Berikut ini adalah hasil penelitian yang dideskripsikan. 
Tabel 1. Data Informan

\begin{tabular}{ccll}
\hline No. & Kode & Peran & Keterangan \\
\hline 1 & P1 & Kepala Sekolah & Daswati R S, S.T, M.Pd. \\
2 & P2 & Wali Kelas & Sekar Mustika W, S.Pd. \\
3 & P3 & Guru Bahasa Indonesia & Endri Padmono F, S.Pd. \\
4 & P4 & Guru Bahasa Indonesia & Elvi Setyaningrum, S.Pd. \\
5 & P5 & Guru Bahasa Indonesia & Wahyu Puspita, S.Pd. \\
6 & P6 & Orang Tua Siswa & Rustinah \\
7 & P7 & Orang Tua Siswa & Ari Fitriyani \\
8 & P8 & Siswa & Pandya Evan \\
9 & P9 & Siswa & Erlangga Rahmatdani \\
10 & P10 & Siswa & Safitri Mardiatil. S. \\
\hline
\end{tabular}

\section{Memberikan Pengalaman Belajar}

Salah satu hal yang ditekankan dalam Surat Edaran (SE) Kementrian Pendidikan dan Kebudayaan (Kemendikbud) Nomor 4 Tahun 2020 tentang pelaksanaan kebijakan pendidikan dalam masa darurat penyebaran Corona Virus Diease (Covid-19) adalah memberikan pengalaman belajar yang bermakna tanpa membebani siswa: "Belajar dari Rumah melalui pembelajaran daring/jarak jauh dilaksanakan untuk memberikan pengalaman belajar yang bermakna bagi siswa, tanpa terbebani tuntutan menuntaskan seluruh capaian kurikulum untuk kenaikan kelas maupun kelulusan" (Kemendikbud, 2020).

Pembelajaran yang dilakukan oleh sekolah mengacu pada Kurikulum 2013. Untuk mendapatkan hasil yang maksimal, persiapan pembelajaran jarak jauh dilaksanakan untuk memberikan pengertian kepada siswa terkait teknis pembelajaran yang akan dilaksanakan selama wabah berlangsung. Persiapan ini dilakukan pada hari terakhir siswa melakukan pembelajaran di sekolah setelah adanya instruksi dari Kemendikbud dan Dinas Pendidikan daerah setempat.. Pembelajaran jarak jauh telah dimulai sejak pertengahan maret 2020. Selain itu tuntutan belajar yang diberikan kepada siswa tidak harus menuntaskan capaian sesuai kurikulum berdasarkan keadaan selama wabah virus Corona. Hal ini disampaikan melalui melalui kuesioner yang diberikan oleh peneliti.
Pembelajaran yang dilakukan tidak harus memenuhi tuntutan seluruh capaian kurikulum, mengingat kondisi seperti saat ini siswa tidak bisa banyak dituntut, begitu juga dengan guru, maka kenaikan dan kelulusan siswa akan menggunakan nilai yang sudah ada. (P1)

Hal diatas juga sesuai dengan hasil penyebaran kuesioner kepada siswa dan wali murid yang juga secara langsung melaksanakan pembelajaran jarak jauh. Pembelajaran yang diterima siswa dirasa cukup dan tidak terbebani dengan tugas. Pelaksanaan pembelajaran yang terjadwal dan dipegang penuh oleh setiap guru mata pelajaran membuat control lebih mudah, selain itu komunikasi yang dilakukan antar guru menciptakan pemberian tugas pembelajaran dapat mempertimbangkan dengan pemberian tugas mata pelajaran lain sehingga tugas dirasa tidak terlalu berat.

Berdasarkan hasil wawancara daring yang dilakukan dengan kepala sekolah, wali kelas, dan guru mata pelajaran Bahasa Indonesia, pembelajaran yang dilaksanakan di SMP Muhammadiyah 1 Prambanan terjadwal secara menetap. Dalam satu hari, pembelajaran dilakukan antara dua sampai tiga mata pelajaran. Hal tersebut dirasa sudah lebih sedikit beban pembelajarannya dari kegiatan pembelajaran yang sebelumnya dilaksanakan di sekolah. Maka, pembelajaran yang dilakukan tidak menghabiskan banyak waktu untuk 
memenuhi dua sampai tiga mata pelajaran perhari.

Hal lain yang menjelaskan bahwa tugas yang diberikan guru tidak memberikan beban terlalu berat kepada siswa adalah teknis pengumpulan tugas. Tenggang waktu pengumpulan tugas biasanya tidak terbatas pada saat hari pembelajaran setiap mata pelajaran, tergantung beban tugas yang diberikan. Pengumpulan biasanya jangka waktu antara 1 hari sampai 1 minggu sebelum hari yang sama dengan pembelajaran di minggu selanjutnya.

Berdasarkan data hasil wawancara dan penyebaran kuesioner kepada kepala sekolah, guru dan siswa dapat pastikan bahwa pembelajaran jarak jauh yang dilakukan di SMP Muhammadiyah 1 Prambanan sesuai dengan instruksi pemerintah melalui SE Mendikbud Nomor 4 Tahun 2020. Beban tugas yang diberikan kepada siswa sesuai dengan kemampuan siswa. Pembelajaran yang dilakukan juga tidak menuntut untuk menuntaskan tuntutan capaian belajar seperti pada capaian yang tertera pada kurikulum. Hal ini dirasa cukup meringankan beban siswa dalam proses pembelajaran jarak jauh selama masa wabah virus Corona berlangsung.

\section{Kecakapan Hidup Mengenai Pandemi}

Pembelajaran jarak jauh yang dilakukan di tengah pandemi wabah virus Corona diterapkan guna memperlambat laju penularan virus. Pola hidup sehat adalah salah satu yang dapat diterapkan oleh masyarakat. Hal itu adalah salah satu yang dapat diajarkan oleh guru yang disangkutkan sesuai mata pelajaran. Sesuai dengan kutipan pada SE Kemendikbud poin 2 bagian b: "Belajar dari Rumah dapat difokuskan pada pendidikan kecakapan hidup antara lain mengenai pandemi Covid-19" (Kemendikbud, 2020).
Dilihat dari perspektif tahapan kebijakan, hasil penelitian menunjukkan bahwa tugas yang diberikan sekolah terkait dengan kecakapan hidup mengenai virus Corona. Hal tersebut disampaikan oleh kepala sekolah yang telah menyampaikan instruksi kepada guru bahwa pembelajaran tidak harus teori seperti pada pembelajaran harian sebelum masa wabah virus Corona, tetapi dapat berupa proyek atau tugas yang berkaitan dengan kecakapan hidup di tengah pandemi virus Corona. Tugas yang diberikan dapat dihubungkan dengan materi pembelajaran yang disangkutkan dengan kecakapan hidup selama wabah virus Corona.

Di sisi lain, guru juga menyampaikan bahwa, pembelajaran yang diberikan kepada siswa menyangkut mengenai virus Corona. Hal tersebut dikemukakan melalui kuesioner yang diberikan kepada wali kelas sebagai perantara tugas dan guru sebagai pemberi tugas kepada siswa.

Tugas yang diberikan sebagian mengenai kecakapan hidup di tengah pandemi virus Corona. Beberapa contoh tugas yang telah diberikan oleh guru mata pelajaran juga sama. Misalnya pada pelajaran Bahasa Indonesia, tugas yang diberikan membuat poster terkait virus Corona, karena sesuai dengan materi pembelajaran. (P3)

Penuturan guru dan wali kelas di atas, sesuai dengan kondisi di lapangan yang disampaikan langsung oleh siswa melalui kuesioner yang telah dibagikan. Contoh tugas yang sampaikan guru sesuai dengan yang disampaikan oleh siswa dan wali murid.

Dari hasil wawancara yang telah dilakukan peneliti dan penyebaran kuesioner, peneliti menemukan bahwa pembelajaran jarak jauh yang dilakukan di SMP Muhammadiyah 1 Prambanan telah mencakup terkait kecakapan hidup di tengah pandemi virus Corona sesuai dengan SE yang dikeluarkan oleh 
Kemendikbud. Data yang diperoleh dari wali kelas, guru, dan peserta didik menunjukkan hasil yang sama.

\section{Pembelajaran Sesuai dengan Kondisi Siswa}

Keberhasilan suatu pembelajaran salah satunya dapat dilihat dari respon siswa. Hal ini akan menjadi tolak ukur kenyamanan siswa dalam mengikuti proses belajar mengajar. Selain itu, fasilitas yang memadai juga dapat mempengaruhi dalam proses pembelajaran. Kelancaran dalam proses akan berakibat pada hasil yang didapatkan oleh siswa.

Dalam prosesnya, pembelajaran jarak jauh memerlukan fasilitas yang berbeda dengan pembelajaran yang dilaksanakan tatap secara langsung. Teknologi informasi modern sangat berpengaruh banyak dalam proses pembelajaran ini. Teknologi tersebut akan mempengaruhi proses kelangsungan pembelajaran secara jarak jauh. Dari hasil penelitian yang dilakukan, persiapan pembelajaran jarak jauh telah dipersiapkan oleh sekolah untuk kelancaran proses belajar mengajar. Persiapan yang dilakukan sekolah salah satunya adalah pelatihan pembuatan Google Formulir untuk guru sebagai referensi media pembelajaran selama wabah virus Corona berlangsung. $\mathrm{Hal}$ tersebut adalah pernyataan yang disampaikan oleh kepala sekolah, wali kelas, dan guru mata pelajaran Bahasa Indonesia.

Peneliti juga telah menarik data dari siswa dan wali murid berdasarkan kuesioner yang telah diisi. Secara keseluruhan, pembelajaran yang dilakukan di SMP Muhammadiyah 1 Prambanan sudah sesuai dengan kondisi siswa. Namun, dari sisi lain terdapat beberapa siswa yang menyampaikan kendala terkait proses pembelajaran jarak jauh.

Pembelajaran jarak jauh tidak ada kesulitan, tetapi kendala yang dialami, kadang tidak bisa mendampingi anak untuk belajar karena harus bekerja. (P7)
Kendala lain yang dihadapi oleh siswa jika pembelajaran jarak jauh dilaksanakan secara daring adalah terkait paket data internet. Terdapat siswa yang mengemukakan jika kesulitan yang mereka alami terkait jaringan dan paket data internet. Selain itu siswa juga mengemukakan bahwa mereka lebih memilih pembelajaran secara langsung di sekolah. Hal tersebut dilandasi beberapa alasan, antara lain: kesulitan komunikasi jika ada yang kurang jelas terkait materi, kurangnya semangat belajar karena tidak ada teman, dan kurang jelas materi yang dipelajari.

Secara garis besar, pembelajaran yang dilaksanakan secara jarak jauh di SMP Muhammadiyah 1 Prambanan sesuai dengan kondisi siswa terkait dengan fasilitas pembelajaran yang digunakan. Hal tersebut telah sesuai dengan SE Mendikbud Nomor 4 Tahun 2020 seperti pada kutipan berikut: "Aktivitas dan tugas pembelajaran Belajar dari Rumah dapat bervariasi antar siswa, sesuai minat dan kondisi masing-masing, termasuk mempertimbangkan kesenjangan akses/ fasilitas belajar di rumah" (Kemendikbud, 2020).

\section{Pemberian Nilai}

Dalam proses belajar mengajar, timbal balik untuk siswa sangat diperlukan. Selain sebagai tolak ukur keberhasilan siswa dalam pembelajaran, timbal balik berupa penilaian akan memacu semangat siswa dalam mengikuti pembelajaran. Maka dari itu proses penilaian perlu diperhatikan dengan baik. Pada pembelajaran biasa, penilaian diolah dalam bentuk skor atau angka sebagai perwujudan dari hasil siswa.

Dalam pembelajaran jarak jauh, penilaian tidak menjadi satu prioritas utama dan tujuan yang akan diperoleh. Pemberian hasil pembelajaran jarak jauh di tengah wabah virus Corona tidak dapat dijadikan sebagai pertimbangan kenaikan 
kelas atau kelulusan siswa. Penilaian yang diberikan tidak mengharuskan dalam bentuk skor atau nilai kualitatif, namun dapat bersifat kualitatif yang bermanfaat untuk siswa. Hal tersebut sesuai dengan kutipan dari SE Pembelajaran Jarak Jauh berikut: "Bukti atau produk aktivitas Belajar dari Rumah diberi umpan balik yang bersifat kualitatif dan berguna dari guru, tanpa diharuskan memberi skor/nilai kuantitatif' (Kemendikbud, 2020).

Hasil penelitian ini diperoleh data bahwa pelaksanaan penilaian dalam pembelajaran jarak jauh di SMP Muhammadiyah 1 Prambanan pemberian skor masih dalam bentuk skor atau kuantitatif. Data tersebut diperoleh dari tiga guru Bahasa Indonesia yang telah mengisi kuesioner penelitian. Hal tersebut belum sesuai dengan kebijakan yang telah disampaikan Kemendikbud melalui SE Pembelajaran Jarak Jauh.

Dalam hal ini pelaksanaan penilaian pembelajaran jarak jauh dalam masa wabah virus Corona belum sesuai dengan Surat Edaran dari Kemendikbud yang diterbitkan pada Nomor 4 Tahun 2020. Penilaian kuantitatif dilakukan karena pembelajaran dan evaluasi dilakukan melalui Google Formulir. Fasilitas yang disediakan oleh Google Formulir adalah koreksi dan penilaian secara otomatis, sehingga hasil rekapitulasi jawaban sudah disertai dengan nilai sesuai pengaturan yang telah diatur saat proses pembuatan soal.

\section{Pembelajaran Bahasa Indonesia}

Kendala pembelajaran jarak jauh selama wabah virus Corona, dialami oleh semua guru mata pelajaran dan siswa. Keadaan baru yang menuntut guru dapat mengembangkan pembelajaran dalam waktu singkat dan persiapan yang minim membuat guru harus memaksimalkan kreativitas, sehingga pembelajaran jarak jauh dapat berjalan dengan baik sesuai dengan kondisi dan keadaan guru maupun siswa. Penambahan wawasan mengenai media dan metode pembelajaran sangat diperlukan oleh semua guru untuk dapat mencapai pembelajaran sesuai dengan kondisi yang sedang berlangsung.

Bahasa Indonesia memiliki empat keterampilan berbahasa yang harus diajarkan, antara lain: menyimak, berbicara, membaca, dan menulis. Pembelajaran dalam Bahasa Indonesia harus disertai dengan keterampilan siswa secara langsung, sehingga siswa tidak hanya paham dalam teori namun juga penerapannya. Hal tersebut juga sebagai tuntutan dalam kurikulum 2013 bahwa penilaian dilakukan terdiri atas dua; penilaian pengetahuan dan penilaian keterampilan.

Selama pembelajaran jarak jauh yang telah dilakukan, guru Bahasa Indonesia melalui kuesioner menyampaikan kesulitan dalam penyampaian materi kepada siswa. Pembelajaran mengalami keterbatasan sehingga tidak dapat dilakukan menggunakan video. Guru melakukan pembelajaran menggunakan bantuan aplikasi WhatsApp, Google Form, Youtube, dan Google Classrom. Keterbatasan yang menghambat, mengakibatkan tidak maksimalnya proses belajar mengajar, sehingga pembelajaran yang disampaikan hanya sebatas pemberian tugas yang berkaitan dengan kecakapan hidup selama wabah virus Corona berlangsung.

Hasil penelitian ini menunjukkan bahwa, guru mengalami kesulitan pembelajaran pada keterampilan berbicara. Kesulitan yang terjadi akibat terbatasnya pembelajaran yang dapat dilakukan secara daring yang mengakibatkan guru tidak dapat mengontrol secara langsung kecakapan siswa dalam mempraktikkan keterampilan berbicaranya.

\section{PENUTUP}

Berdasarkan analisis dan pembahasan, dapat disimpulkan bahwa pelaksanaan kebijakan pembelajaran jarak 
jauh dalam masa wabah virus Corona di SMP Muhammadiyah 1 Prambanan sebagai berikut. Pembelajaran jarak jauh yang dilakukan memberikan pengalaman belajar siswa dan tidak memberikan beban yang berlebih untuk guru, wali murid, maupun siswa. Selama proses pembelajaran jarak jauh diselipkan beberapa pembelajaran mengenai kecakapan hidup di tengah wabah virus Corona.

Sekolah menggunakan kurikulum 2013 sebagai pedoman dalam memberikan materi pembelajaran kepada siswa. Pengajaran yang dilakukan oleh guru dilihat sesuai dengan kondisi siswa. Hal ini memperhatikan kesanggupan dan fasilitas yang dimiliki siswa dapat menjangkau tugas yang diberikan oleh guru. Kendala pembelajaran tetap ditemui oleh siswa yang berakibat guru harus memberikan solusi lain agar siswa dapat mengikuti pembelajaran secara penuh. Penilaian yang dilakukan untuk tugas-tugas yang diberikan selama pembelajaran jarak jauh dilakukan dalam bentuk skor atau kuantitatif, sehingga belum sesuai dengan Surat Edaran dari Kemendikbud. Dalam pembelajaran Bahasa Indonesia, guru masih menemukan beberapa kendala dalam mengajarkan 4 keterampilan pembelajaran, terutama keterampilan berbicara. Hasil penelitian ini menunjukkan: Beban pembelajaran yang diberikan kepada siswa tidak memberatkan dari segi materi, sarana, dan prasarana. Pembelajaran yang diajarkan telah mencakup kecakapan hidup dalam masa wabah virus Corona. Metode dan proses pembelajaran yang dilaksanakan sesuai dengan kondisi siswa. Umpan balik yang diberikan guru masih berupa poin dan belum sesuai dengan instruksi pemerintah. Pembelajaran bahasa Indonesia yang dilakukan telah sesuai dengan instruksi pemerintah.

Dalam pelaksanaan kebijakan pembelajaran jarak jauh ini diharapkan sekolah benar-benar menerapkan sesuai dengan instruksi pemerintah. Secara keseluruhan SMP Muhammadiyah 1 Prambanan telah menerapkan sebagian besar ketentuan pembelajaran yang telah di instruksikan melalui SE Nomor 4 Tahun 2020 tentang pembelajaran jarak jauh selama wabah virus Corona.

\section{DAFTAR PUSTAKA}

Aziza, L., Aqmarina, A., \& Ihsan, M. (Ed.). (2020). Pedoman Pencegahan dan Pengendalian Coronavirus Disease (Covid19). Jakarta: Kementerian Kesehatan RI.

Dewi, N., Murtinugraha, R. E., \& Arthur, R. (2018). Pengembangan Media Pembelajaran Interaktif pada Mata Kuliah Teori dan Praktik Plambing di Program Studi S1 PVK UNJ. Jurnal PenSil, 7(2), 25-34. https://doi.org/10.21009/pensil.7.2 .6

Elvarita, A., Iriani, T., \& Handoyo, S. S. (2020). Pengembangan Bahan Ajar Mekanika Tanah Berbasis E-Modul Pada Program Studi Pendidikan Teknik Bangunan, Universitas Negeri Jakarta. Jurnal PenSil, 9(1), 17.

https://doi.org/10.21009/jpensil.v9 i1.11987

Hasamah. (2014). Pembelajaran Bauran (Blended Learning). Jakarta: Prestasi Pustaka Publiser.

Kemendikbud. (2020). Surat Edaran Kemendikbud Nomor 4 Tabun 2020 tentang Pelaksanaan Kebijakan Pendidikan dalam Masa Darurat Penyebaran Corona Virus Diease (Covid19). Jakarta: Kementerian Pendidikan dan Kebudayaan Republik Indonesia.

Moleong, L. J. (2014). Metode Penelitian Kualitatif. Bandung: Remaja Rosdakarya.

Ningtyas, D. K., Virnawati, F., Prasetiyo, Paramitta, T., \& Simri, I. W. (2008). Analisis Perilaku Pengguna Sistem ELearning Universitas Gunadarma. 
Seminar Ilmiah Nasional Komputer dan Sistem Intelijen (KOMMIT 2008), 512516. Depok: Universitas Gunadarma. Diambil dari http://repository.gunadarma.ac.id/8 1/1/79.pdf

Noesgaard, S. S., \& Ørngreen, R. (2015). The Effectiveness of E-Learning: An Explorative and Integrative Review of the Definitions, Methodologies and Factors that Promote e-Learning Effectiveness. The Electronic Journal of e-Learning, 13(4), 277-289. Diambil dari

http://ejel.org/issue/download.htm l:idArticle $=438$

Tampubolon, M. A. W., Arthur, R., \& Daryati, D. (2017). Pengembangan E-Module Konstruksi Bangunan pada Kompetensi Dasar Menerapkan
Spesifikasi dan Karteristik Kayu. Jurnal PenSil, 6(2), 75-82. https://doi.org/10.21009/jpensil.v6 i2.7241

Tigowati, Efendi, A., \& Budiyanto, C. W. (2017). The Influence of E-learning Use to Student Cognitive Performance and Motivation in Digital Simulation Course. Indonesian Journal of Informatics Education, 1(1), 127-134.

https://doi.org/10.20961/ijie.v1i2.1 2812

Yaumi, M. (2007). The Implementation of Distance Learning in Indonesian Higher Education. Lentera Pendidikan: Jurnal Ilmu Tarbiyah dan Keguruan, 10(2), 196-215. https://doi.org/10.24252/lp.2007v1 0n2a6 
